\title{
OCENA NAWYKÓW ŻYWIENIOWYCH WŚRÓD CHORYCH Z OSTRYM I PRZEWLEKŁYM ZAPALENIEM TRZUSTKI
}

\section{DIETARY HABITS OF PATIENTS WITH ACUTE AND CHRONIC PANCREATITIS}

\author{
Martyna Radecka ${ }^{1}$, Anna Ukleja ${ }^{1}$, Aneta Jachnis $^{2}$, Michał Ławiński $^{2}$ \\ ${ }^{1}$ Zakład Żywienia Człowieka \\ Warszawski Uniwersytet Medyczny \\ ${ }^{2}$ Katedra i Klinika Chirurgii Ogólnej, Gastroenterologicznej i Onkologicznej \\ Warszawski Uniwersytet Medyczny.
}

DOI: https://doi.org/10.20883/pielpol.2017.4

\section{STRESZCZENIE}

Wstęp. W warunkach polskich alkohol oraz kamica żółciowa są głównymi czynnikami rozwoju ostrego zapalenia trzustki (OZT), które z czasem może przejść w inną jednostkę chorobową określaną jako przewlekłe zapalenia trzustki (PZT). Stan zapalny trzustki może powodować poważne zaburzenia trawienia tłuszczów oraz gospodarki węglowodanowej. Nieleczone zapalenie trzustki może prowadzić do poważnych powikłań, a nawet do zgonu. Dlatego ważna jest wczesna diagnoza zapalenia trzustki oraz wdrożenie skutecznego leczenia. W rozwoju zapalenia trzustki ważną rolę odgrywa odpowiednia dieta, której przestrzeganie ma na celu złagodzenie objawów choroby, polepszenie komfortu życia oraz zapobiega występowaniu powikłań. Cel. Celem pracy była ocena nawyków żywieniowych chorych z ostrym i przewlekłym zapaleniem trzustki.

Materiał i metody. W badaniu wzięło udział 31 osób, w tym 10 kobiet i 21 mężczyzn, w wieku od 20 do 57 lat, u których zdiagnozowano ostre lub przewlekłe zapalenie trzustki.

Wyniki. U chorych na PZT najczęściej towarzyszącymi jednostkami chorobowymi były: cukrzyca, kamica żółciowa, zaburzenia lipidowe oraz choroby serca. W grupie tej na cukrzyce chorowało $75 \%$ kobiet i $36 \%$ mężczyzn. W grupie z OZT $80 \%$ kobiet i $82 \%$ mężczyzn w żywieniu stosowało tradycyjną kuchnię polską. Tylko $20 \%$ kobiet spożywało potrawy lekkostrawne, żaden z mężczyzn nie spożywał pokarmów lekkostrawnych. W grupie z OZT żywność typu fast food preferowało $18 \%$ mężczyzn. W grupie osób chorych na PZT 100\% kobiet oraz 81,8\% mężczyzn stosowało tradycyjną kuchnię polską.

Wnioski. U większości chorych z OZT i PZT występuje nadwaga. Cukrzyca jest najczęstszą towarzyszącą jednostką chorobową wśród chorych na OZT i PZT. Zaleceń żywieniowych dotyczących diety łatwo strawnej z ograniczeniem tłuszczów przestrzega mniej więcej połowa badanych. Dominującą techniką kulinarną wykorzystywaną przez chorych z OZT iPZT jest smażenie. Większość chorych na OZT i PZT nie wykazuje chęci zmiany nawyków żywieniowych i rezygnacji ze szkodliwych używek (alkoholu i papierosów).

SŁOWA KLUCZOWE: ostre zapalenie trzustki, przewlekłe zapalenia trzustki, żywienie.

\begin{abstract}
Introduction. In Poland alcohol and gallstones are the main factors for the development of acute pancreatitis, which sometimes can become chronic pancreatitis. Inflammation of the pancreas can cause serious digestive disorders of fat and carbohydrates. Untreated, pancreatitis may cause serious complications and even lead to death. That is why it is important to early diagnose pancreatitis and implement effective treatment. In the development of pancreatitis an important role plays proper diet, compliance with which aims to alleviate symptoms, improve quality of life and prevent complications.

Aim. To assess the eating habits of patients with acute and chronic pancreatitis.

Material and methods. The study involved 31 people, including 10 women and 21 men at the age of 20 to 57 years who were diagnosed with acute or chronic pancreatitis.

Results. In patients with chronic pancreatitis usually associated disease entities were: diabetes, gallstones, lipid disorders and heart disease. In this group of patients $75 \%$ of women and $36 \%$ men suffered from diabetes. In the group with acute pancreatitis $80 \%$ of women and $82 \%$ of men used traditional Polish cuisine. Only $20 \%$ of women consumed food easily digestible, none of the men did eat easily digestible foods. In the group with acute pancreatitis $18 \%$ of men preferred fast food. In people with chronic pancreatitis $100 \%$ women and $81.8 \%$ of men used traditional Polish cuisine.

Conclusions. The majority of patients with acute pancreatitis and chronic pancreatitis are overweight. Diabetes is the most common concomitant disease entity among patients with acute and chronic pancreatitis. Nutritional recommendations regarding easily digestible diet with restriction of fats are respected by about half of the respondents. The dominant culinary technique used by patients with acute and chronic pancreatitis is frying. Most patients with acute and chronic pancreatitis show no willingness to change eating habits and abandon the harmful stimulants (alcohol and cigarettes).
\end{abstract}

KEYWORDS: acute pancreatitis, chronic pancreatitis, nutrition. 


\section{Wstęp}

Ostre zapalenie trzustki to stan zapalny gruczołu związany z przedwczesną aktywacją proenzymów trzustkowych i uszkodzeniem - w różnym stopniu - sąsiadujących tkanek i niekiedy też odległych narządów [1]. Do najczęstszych czynników powodujących OZT należą alkohol oraz choroby pęcherzyka żółciowego i dróg żółciowych [2]. Pierwszym, głównym objawem jest nagły, bardzo silny ból w nadbrzuszu lub górnym lewym kwadrancie brzucha. Często pojawiają się również nudności i wymioty, a także gorączka [3]. W leczeniu ostrego zapalenia trzustki ważną rolę odgrywa odpowiednie postępowanie dietetyczne. Zazwyczaj wprowadza się żywienie doustne po ustąpieniu bólów brzucha, w 3.-4. dobie. Zaleca się dietę łatwo strawną, półpłynną. Pierwsze posiłki powinny być niskokaloryczne, ubogotłuszczowe oraz małe objętościowo. Stopniowo należy zwiększać kaloryczność posiłków i ich ilość w ciągu dnia. W przypadku wystąpienia powikłań stosuje się żywienie dojelitowe lub całkowite żywienie pozajelitowe, w zależności od stopnia nasilenia zaburzeń. Żywienie drogą doustną można rozpocząć po wznowieniu perystaltyki jelit oraz braku powikłań, głównie zakażeń bakteryjnych [4]. W profilaktyce wystąpienia nawrotów ostrego zapalenia trzustki bardzo ważne jest zaprzestanie spożywania alkoholu oraz leczenie chorób będących przyczyną zaburzeń pracy narządu. Duże znaczenie ma również zmiana nawyków żywieniowych oraz stosowanie diety łatwo strawnej z ograniczeniem tłuszczów [3]. Przewlekłe zapalenie trzustki to chroniczny proces zapalny, którego skutkiem są stopniowe zmiany w miąższu trzustki (włóknienie i zanik) oraz postępujący rozwój niewydolności czynności zewnątrzwydzielniczej i wewnątrzwydzielniczej trzustki [5]. Wśród przyczyn przewlekłego zapalenia trzustki wyróżnia się czynniki toksyczno-metaboliczne. Najważniejsze $z$ nich to spożywanie alkoholu oraz palenie tytoniu. Wymienia się także inne przyczyny: hiperkalcemię, hiperlipidemię, przewlekłą niewydolność nerek, nadużywanie leków oraz działanie toksyn [6]. Do wczesnych objawów przewlekłego zapalenia trzustki należą ból brzucha oraz żółtaczka. Ból zazwyczaj jest bardzo silny, obejmuje nadbrzusze, często promieniuje do pleców. W przebiegu PZT dochodzi do upośledzenia czynności zewnątrzwydzielniczej trzustki, z czym wiążą się następujące objawy: wzdęcia, uczucie pełności, wymioty oraz przewlekła biegunka tłuszczowa. Są one skutkiem zaburzeń wydzielania lipazy trzustkowej i jej szybszej inaktywacji [7]. Dieta osób chorych na przewlekłe zapalenie trzustki powinna być dietą o zwiększonej podaży energii. Ważne jest, aby spożywać 5-6 posiłków dziennie, mniejszych objętościowo, o odpowiedniej kaloryczności i o regular- nych porach. Według najnowszych wytycznych dieta łatwo strawna z ograniczeniem tłuszczów zalecana jest jedynie w przypadku występowania biegunki tłuszczowej i dolegliwości bólowych, gdyż niedostateczna podaż tłuszczów z dietą może wpływać na pogorszenie stanu odżywienia chorego oraz utrudnienie wchłaniania witamin rozpuszczalnych w tłuszczach [8, 9].

Celem pracy jest ocena nawyków żywieniowych chorych z ostrym i przewlekłym zapaleniem trzustki.

\section{Materiał i metody}

W badaniu wzięło udział 31 osób, w tym 10 kobiet i 21 mężczyzn, w wieku od 20 do 57 lat. Kryterium włączenia do badania było rozpoznanie ostrego lub przewlekłego zapalenia trzustki. Badania przeprowadzone zostały na Oddziale Chorób Wewnętrznych i Gastroenterologii w Mazowieckim Szpitalu Bródnowskim w Warszawie w terminie od lutego do czerwca 2015 r. Jako narzędzie badawcze służące zgromadzeniu danych wykorzystano autorski kwestionariusz ankiety. Pytania dotyczyły ostrego lub przewlekłego zapalenia trzustki, czasu od momentu zachorowania oraz obecności chorób współistniejących. W dalszej części kwestionariusza pytania dotyczyły stylu życia, przestrzegania diety łatwo strawnej z ograniczeniem tłuszczów, palenia tytoniu oraz spożywania alkoholu. Ostatnią część ankiety stanowiły pytania charakteryzujące respondenta: płeć, wiek, miejsce zamieszkania, masa ciała, wzrost. W wyniku estymacji klasyczną metodą najmniejszych kwadratów z wykorzystaniem programu do modelowania ekonometrycznego Gretl otrzymano liniowy model prawdopodobieństwa, wykorzystując do tego celu 31 obserwacji. Zmienna zależna (Y) jest zmienną 0-1, która przyjmuje wartość 0 dla ostrego zapalenia trzustki i 1 dla przewlekłego zapalenia trzustki. Zmienna objaśniana Y była determinowana przez następujące zmienne objaśniające: picie alkoholu, palenie papierosów, wiek oraz płeć w grupie respondentów. Na poziomie istotności $p=0,1$ istotnymi zmiennymi objaśniającymi były: palenie papierosów oraz spożywanie alkoholu. Pozostałe zmienne objaśniające okazały się nieistotne statystycznie przy zakładanym poziomie istotności $p=0,1$. Przyczyną braku istotności części danych zebranych z ankiety był brak zróżnicowania między zachorowaniem na PZT i OZT w obrębie danej zmiennej. Na podstawie testu Walda, na poziomie istotności $p=0,1$, odrzucono hipotezę zerową, według której wszystkie zmienne objaśniające w modelu są łącznie nieistotne dla kształtowania się zmiennej objaśnianej. Oznacza to, że w szacowanym modelu istnieje przynajmniej jeden parametr istotny statystycznie i różny od zera - w modelu są to zmienne: palenie papierosów i spożywanie alkoholu. 


\section{Wyniki}

Struktura płci w grupie osób zarówno z przewlekłym jak i ostrym zapaleniem trzustki kształtowała się podobnie. W grupie osób z PZT i OZT średnie wartości wskaźnika BMI przedstawiono w tabeli 1.

Tabela 1. Wskaźnik masy ciała respondentów $w \mathrm{~kg} / \mathrm{m}^{2}(\mathrm{n}=31)$ Table 1. Body mass index of respondents $\left[\mathrm{kg} / \mathrm{m}^{2}\right](n=31)$

\begin{tabular}{ccc}
\hline & BMI & \\
& PZT/AP & OZT/CP \\
\hline Kobiety/Female & 23,34 & 25,86 \\
Mężczyźni/Male & 27,93 & 28,26 \\
\hline
\end{tabular}

Źródło: opracowanie własne

Source: author's own analysis

U chorych na PZT najczęściej towarzyszącymi jednostkami chorobowymi były: cukrzyca, kamica żółciowa, zaburzenia lipidowe oraz choroby serca. Na cukrzycę chorowało $75 \%$ kobiet i 36\% mężczyzn. Osoby chore na OZT najczęściej stosowały tradycyjną kuchnię polską - 80\% kobiet i prawie $82 \%$ mężczyzn. Tylko 20\% kobiet spożywało potrawy lekkostrawne, żaden z mężczyzn nie spożywał pokarmów lekkostrawnych. Ponad $18 \%$ mężczyzn preferowało żywność typu fast food. W grupie osób chorych na PZT 100\% kobiet oraz 81,8\% mężczyzn stosowało tradycyjną kuchnię polską.

W badanej grupie osób poddano analizie stosowanie i przestrzeganie diety łatwo strawnej z ograniczeniem tłuszczów. W grupie z PZT 25\% kobiet oraz 54,5\% mężczyzn stosowało dietę łatwo strawną z ograniczeniem tłuszczów i przestrzegało tych zaleceń dietetycznych, zaś w grupie osób z OZT dietę łatwo strawną z ograniczeniem tłuszczów stosowało odpowiednio $60 \%$ kobiet i 45,5\% mężczyzn. Szczegółowe wyniki przedstawiono w tabeli 2.

Tabela 2. Stosowanie i przestrzeganie diety łatwo strawnej z ograniczeniem tłuszczów wśród chorych na PZT i OZT ( $n=31)$

Table 2. Providing and adherence to easily digestible diet with restriction of fats in patients with $A P$ and $C P(n=31)$

\begin{tabular}{|c|c|c|c|c|}
\hline \multicolumn{5}{|c|}{$\begin{array}{l}\text { Stosowanie i przestrzeganie diety łatwo strawnej z ograniczeniem tłusz- } \\
\text { czów/Providing and adherence to diet with restriction of fats }\end{array}$} \\
\hline & & $\begin{array}{l}\text { Stosuję i prze- } \\
\text { strzegam/l use and } \\
\text { respect }\end{array}$ & $\begin{array}{c}\text { Stosuje, } \\
\text { ale nie przestrze- } \\
\text { gam// use, but do } \\
\text { not respect }\end{array}$ & $\begin{array}{c}\text { Nie } \\
\text { stosuję/l do not } \\
\text { use }\end{array}$ \\
\hline \multirow{2}{*}{$\begin{array}{l}\mathrm{PZT} / \\
\mathrm{CP}\end{array}$} & $\begin{array}{l}\text { kobiety/ } \\
\text { female }\end{array}$ & $25,0 \%$ & $25,0 \%$ & $50,0 \%$ \\
\hline & $\begin{array}{l}\text { mężczyźni/ } \\
\text { male }\end{array}$ & $54,5 \%$ & $27,3 \%$ & $18,2 \%$ \\
\hline \multirow{2}{*}{$\begin{array}{l}\mathrm{OZT} / \\
\mathrm{AP}\end{array}$} & $\begin{array}{l}\text { kobiety/ } \\
\text { female }\end{array}$ & $60,0 \%$ & $20,0 \%$ & $20,0 \%$ \\
\hline & $\begin{array}{l}\text { mężczyźni/ } \\
\text { male }\end{array}$ & $45,5 \%$ & $9 \%$ & $45,5 \%$ \\
\hline
\end{tabular}

Źródło: opracowanie własne

Source: author's own analysis
Wśród respondentów z przewlekłym zapaleniem trzustki odnotowano mniejszy odsetek palących kobiet i mężczyzn w porównaniu do grupy osób z ostrym zapaleniem trzustki. W grupie z ostrym zapaleniem trzustki 70\% mężczyzn i 50\% kobiet pali papierosy (Tabela 3).

Tabela 3. Palenie papierosów wśród osób chorych na PZT i OZT ( $\mathrm{n}=31)$ Table 3. Smoking cigarettes among people with $A P$ and $C P(n=31)$

\begin{tabular}{|c|c|c|c|c|c|}
\hline & \multicolumn{5}{|c|}{ Czy i jak często palisz papierosy?/Do you smoke and how often? } \\
\hline & & $\begin{array}{c}\text { Palę/ } \\
\text { Smoker }\end{array}$ & $\begin{array}{c}\text { Nie palę/ } \\
\text { Non smoker }\end{array}$ & $\begin{array}{l}\text { Sporadycznie/ } \\
\text { Sometimes }\end{array}$ & $\begin{array}{l}\text { Palenie rzucone } \\
\text { w momencie } \\
\text { zachorowania/ } \\
\text { Stopped smoking } \\
\text { because of disease }\end{array}$ \\
\hline \multirow{2}{*}{$\begin{array}{c}\mathrm{PZT} / \\
\mathrm{CP}\end{array}$} & $\begin{array}{l}\text { kobiety/ } \\
\text { female }\end{array}$ & $64 \%$ & $36 \%$ & $27 \%$ & $0 \%$ \\
\hline & $\begin{array}{c}\text { mężczyźni/ } \\
\text { male }\end{array}$ & $25 \%$ & $75 \%$ & $50 \%$ & $25 \%$ \\
\hline \multirow{2}{*}{$\begin{array}{l}\text { OZT/ } \\
\text { AP }\end{array}$} & $\begin{array}{c}\text { kobiety/ } \\
\text { female }\end{array}$ & $70 \%$ & $30 \%$ & $10 \%$ & $0 \%$ \\
\hline & $\begin{array}{c}\text { mężczyźni/ } \\
\text { male }\end{array}$ & $50 \%$ & $50 \%$ & $33 \%$ & $10 \%$ \\
\hline
\end{tabular}

Źródło: opracowanie własne

Source: author's own analysis

W grupie osób zarówno z przewlekłym, jak i ostrym zapaleniem trzustki spożycie alkoholu wśród mężczyzn było wyższe niż u kobiet. Wszyscy mężczyźni z PZT spożywali alkohol przed diagnozą. Mężczyźni z OZT w $70 \%$ zadeklarowali, że pomimo choroby nie zrezygnowali ze spożycia alkoholu. Podobny wynik zaobserwowano w grupie kobiet z OZT - aż 67\% badanych kobiet przyznało się do spożywania alkoholu, choć wiedziały, że ma to niekorzystny wpływ na przebieg choroby (Tabela 4).

Tabela 4. Spożywanie alkoholu przez osoby chore na PZT i OZT $(\mathrm{n}=31)$ Table 4. Alcohol consumption by people with PZT and AP $(n=31)$

\begin{tabular}{|c|c|c|c|c|c|}
\hline \multicolumn{6}{|c|}{ Czy i jak często spożywasz alkohol?/Do you consume alcohol and how often? } \\
\hline & & Tak/Yes & $\mathrm{Nie} / \mathrm{No}$ & $\begin{array}{c}\text { Sporadycznie/ } \\
\text { Sometimes }\end{array}$ & $\begin{array}{l}\text { Nie piję od momen- } \\
\text { tu zachorowania/ } \\
\text { I have not drunk } \\
\text { since getting sick }\end{array}$ \\
\hline \multirow{2}{*}{$\begin{array}{l}\mathrm{PZT} / \\
\mathrm{CP}\end{array}$} & $\begin{array}{l}\text { kobiety/ } \\
\text { female }\end{array}$ & $73 \%$ & $27 \%$ & $0 \%$ & $27 \%$ \\
\hline & $\begin{array}{l}\text { mężczyźni/ } \\
\text { male }\end{array}$ & $25 \%$ & $75 \%$ & $25 \%$ & $50 \%$ \\
\hline \multirow{2}{*}{$\begin{array}{l}\text { OZT/ } \\
\mathrm{AP}\end{array}$} & $\begin{array}{l}\text { kobiety/ } \\
\text { female }\end{array}$ & $70 \%$ & $30 \%$ & $10 \%$ & $20 \%$ \\
\hline & $\begin{array}{l}\text { mężczyźni/ } \\
\text { male }\end{array}$ & $67 \%$ & $33 \%$ & $17 \%$ & $0 \%$ \\
\hline
\end{tabular}

Źródło: opracowanie własne

Source: author's own analysis 


\section{Dyskusja}

Wiek osób chorych na OZT i PZT mieści się w przedziale 39-45 lat. Podobny przedział wiekowy (35-45 lat) odnotowano w innym badaniu [10]. Wyniki niniejszych badań własnych wykazują, że zapadalność na ostre i przewlekłe zapalenie trzustki jest wyższa u mężczyzn niż u kobiet. W innych badaniach nie wykazano istotnej różnicy pod względem śmiertelności w zależności od płci chorych na schorzenia trzustki [11]. Analiza BMI wśród badanych zarówno kobiet, jak i mężczyzn chorych na OZT i PZT wskazuje na współistnienie nadwagi. W przeprowadzonych podobnych badaniach wykazano, że zwiększona objętość wewnątrzbrzusznej tkanki tłuszczowej miała znaczący wpływ na wystąpienie ciężkiego przebiegu choroby [12]. Nadwaga oraz otyłość mogą również zwiększać prawdopodobieństwo wystąpienia powikłań ogólnoustrojowych oraz śmiertelność, dlatego też pomiary objętości wewnątrzbrzusznej tkanki tłuszczowej mogą stać się istotnym czynnikiem w prognozowaniu ciężkości przebiegu chorób trzustki. Najczęściej występującą chorobą współistniejącą z OZT i PZT była cukrzyca, na którą choruje 75\% kobiet oraz 36\% mężczyzn z przewlekłym zapaleniem trzustki. Analizy innych badaczy wykazały, iż występowanie PZT, cukrzycy oraz kamicy żółciowej może zwiększać ryzyko rozwoju raka trzustki [13, 14]. Z najwyższym ryzykiem rozwoju raka tego narządu wiąże się natomiast występowanie PZT wraz z współistniejącą cukrzycą. Ważną rolę w leczeniu dietetycznym osób chorych na ostre i przewlekłe zapalenie trzustki odgrywa stosowanie odpowiednich technik kulinarnych. Wyniki badań własnych wykazują, że smażenie preferują chorzy zarówno na OZT, jak i PZT. Równie często stosowane jest gotowanie oraz pieczenie. Gotowanie, duszenie bez obsmażania oraz pieczenie w foli bez tłuszczu są zalecane jako odpowiednie techniki kulinarne [10]. Niedozwolone jest natomiast smażenie, tak często wskazywane przez respondentów. Wyniki te sugerują, iż należy dążyć do wprowadzenia zmiany nawyków żywieniowych osób chorych na OZT i PZT w celu wspomagania procesu leczenia i poprawy stanu zdrowia. W leczeniu dietetycznym zmian zapalnych trzustki stosuje się dietę łatwo strawną z ograniczeniem tłuszczów. Wyniki badań wykazały, iż mniej więcej połowa mężczyzn chorych na ostre i przewlekłe zapalenie trzustki stosuje tę dietę oraz przestrzega jej zasad, podobnie jak większość kobiet cierpiących na ostre zapalenie trzustki. Natomiast stosowanie i przestrzeganie diety potwierdza zaledwie 25\% kobiet, u których zdiagnozowano przewlekłe zapalenie trzustki. Według zespołu ekspertów stosowanie diety łatwo strawnej z ograniczeniem tłuszczów ma znaczenie w leczeniu dietetycznym chorób trzustki w celu zapobiegania występowaniu biegunki tłuszczo- wej oraz w przypadku nieefektywnej substytucyjnej terapii enzymatycznej [15]. W innych przypadkach nie ma konieczności ograniczania tłuszczów w diecie, gdyż ich niedobór może prowadzić do pogorszenia stanu odżywienia chorego oraz zaburzeń wchłaniania witamin rozpuszczalnych w tłuszczach. U chorych niedożywionych bądź mających trudności w osiąganiu przyrostów masy ciała zalecane jest nawet wyższe spożycie tłuszczów niż dla osoby zdrowej (powyżej 30\% dziennego zapotrzebowania energetycznego). W związku ze stosowaniem odpowiedniej diety przez niewielki odsetek chorych istotne jest prowadzenie edukacji żywieniowej w celu zmiany nieodpowiednich nawyków i zapobiegania powikłaniom choroby. Wyniki badań wykazały, że palenie papierosów może w większym stopniu wpływać na rozwój przewlekłego zapalenia trzustki niż ostrego zapalenia trzustki. Zdecydowana większość mężczyzn chorych na wyżej wymienione jednostki chorobowe zadeklarowała palenie tytoniu. Papierosy pali również połowa kobiet cierpiących na ostre zapalenie trzustki oraz jedna czwarta kobiet z przewlekłym zapaleniem trzustki, część z nich rzuciła palenie w związku z rozpoznaniem choroby. Rekomendacje Grupy Roboczej Konsultanta Krajowego w dziedzinie Gastroenterologii i Polskiego Klubu Trzustkowego wskazują, że palenie tytoniu stanowi niezależną przyczynę powstawania chorób trzustki. Zwiększa ono także prawdopodobieństwo rozwoju raka trzustki u chorych na przewlekłe zapalenie. Chorym na ostre i przewlekłe zapalenie trzustki zaleca się zaprzestanie palenia tytoniu, co prowadzi do spowolnienia rozwoju choroby, zapobiega występowaniu dolegliwości bólowych oraz zmniejsza prawdopodobieństwo rozwoju powikłań. Alkohol jest główną przyczyną zarówno ostrego, jak i przewlekłego zapalenia trzustki. Dane z piśmiennictwa wykazały, iż nadużywanie alkoholu stanowi przyczynę 70-90\% zachorowań [10, 15]. Wyniki badań wykazały spożycie napojów alkoholowych u blisko 70\% mężczyzn cierpiących na ostre i przewlekłe zapalenie trzustki. Podobnie wyniki odnotowano u kobiet chorych na ostre zapalenie trzustki. Wyjątek stanowią kobiety, u których zdiagnozowano przewlekłe zapalenie trzustki - spożywanie alkoholu potwierdziło 25\% badanych kobiet. Na rozwój i przebieg ostrego oraz przewlekłego zapalenia trzustki największy wpływ wywierają częstotliwość i regularność spożywania alkoholu, niezależnie od jego ilości oraz rodzaju. Z przeprowadzonych badań własnych wynika, iż połowa mężczyzn chorych na przewlekłe zapalenie trzustki oraz nadużywających alkoholu spożywa go codziennie lub kilka razy w tygodniu, podobnie kształtuje się spożycie napojów alkoholowych wśród mężczyzn i kobiet cierpiących na ostre zapalenie trzustki, zaś kobiety ze zdiagnozowanym przewlekłym zapaleniem trzustki spożywają napoje wysokoprocen- 
towe raz w miesiącu. Rekomendacje Grupy Roboczej Konsultanta Krajowego w dziedzinie Gastroenterologii i Polskiego Klubu Trzustkowego wskazują na ogromną rolę zaprzestania spożywania alkoholu w leczeniu chorych na ostre i przewlekłe zapalenie trzustki [15]. Zalecana jest całkowita abstynencja alkoholowa, która przyczynia się do poprawy stanu i jakości życia chorego, spowolnienia rozwoju choroby, a także zmniejszenia ilości epizodów napadowego bólu brzucha. Wyniki badań własnych wykazały, że zasadne jest prowadzenie wśród chorych na schorzenia trzustki edukacji dotyczącej zmiany nawyków oraz prowadzenia zdrowego trybu życia.

\section{Wnioski}

1. U większości chorych z OZT i PZT występuje nadwaga. Cukrzyca jest najczęstszą towarzyszącą jednostką chorobową wśród chorych na OZT i PZT.

2. Zaleceń żywieniowych dotyczących diety łatwo strawnej z ograniczeniem tłuszczów przestrzega mniej więcej połowa badanych.

3. Dominującą techniką kulinarną wykorzystywaną przez chorych z OZT i PZT jest smażenie.

4. Większość chorych na OZT i PZT nie wykazuje chęci zmiany nawyków żywieniowych i rezygnacji ze szkodliwych używek (alkoholu i papierosów)

\section{Piśmiennictwo}

1. Gajewski P, Szczeklik A. Interna Szczeklika 2013. Podręcznik chorób wewnętrznych. Kraków: Medycyna Praktyczna; 2013. 993-1008.

2. Ledóchowski M, Sieklucki J, Tarnowski W. Wyniki leczenia ostrego zapalenia trzustki. 25-letnie doświadczenia Kliniki. Post Nauk Med. 2014; 27(8): 555-558.

3. Jarosz M. Praktyczny podręcznik dietetyki. Warszawa: Wyd. IŻŻ; 2010. 275-290.

4. Grzymisławski M. Leczenie żywieniowe w ostrym zapaleniu trzustki. Gastroenterol Pol. 2008; 15(1): 63-66.

5. Poniewierka E, Neubauer K. Historia naturalna przewlekłego zapalenia trzustki. Gastroenterol Pol. 2007; 14(3): 213-215.

6. Czeczot H, Ścibior D, Skrzycki M. Peroksydacja lipidów w surowicy krwi chorych z zapaleniem i rakiem trzustki. Gastroenterol Pol. 2007; 14(1): 13-16.
7. Stasiak M, Gąsiorowska A. Znaczenie testów oceniających czynność zewnątrzwydzielniczą w diagnostyce przewlekłego zapalenia trzustki. Gastroenterol Pol. 2013; 20(3): 99-104.

8. Celiński K, Mądro A, Słomka M. Zasady żywienia w przewlekłym zapaleniu trzustki $z$ uwzględnieniem okresów zaostrzeń. Gastroenterol Pol. 2007; 14(4): 295-297.

9. Leksowski K, Tomaszewski S. Leczenie bólu spowodowanego przewlekłym zapaleniem trzustki. Gastroenterol Pol. 2007; 14(5): 372-376.

10. Włochal M, Grzymisławski M. Rola żywienia w leczeniu przewlekłego zapalenia trzustki. Piel Zdr Publ. 2013; 3(3): 303-310.

11. Lu CW, Liu LC, Hsieh YC. Increased admission serum estradiol level is correlated with high mortality in patients with severe acute pancreatitis. J Gastroenterol. 2013; 48(3): 374-381.

12. O'Leary DP, O'Neill D, McLaughlin P. Effects of abdominal fat distribution parameters on severity of acute pancreatitis. World J Surg. 2012; 36: 1679-1685.

13. Lai HC, Tsai IJ, Chen PC. Gallstones, a cholecystectomy, chronic pancreatitis, and the risk of subsequent pancreatic cancer in diabetic patients: a population-based cohort study. J Gastroenterol. 2013; 48(6): 721-727.

14. Liao KF, Lai SW, Li Cl, Chen WC. Diabetes mellitus correlates with increased risk of pancreatic cancer: a population-based cohort study in Taiwan. J Gastroenterol Hepatol. 2012; 27: 709-713.

15. Żuk K, Czkwianianc E, Degowska M. Zalecenia diagnostyczne i terapeutyczne w przewlekłym zapaleniu trzustki. Rekomendacje Grupy Roboczej Konsultanta Krajowego w dziedzinie Gastroenterologii i Polskiego Klubu Trzustkowego. Prz Gastroenterol. 2011; 6(6): 339-342.

Artykuł przyjęty do redakcji: 04.05.2016

Artykuł przyjęty do publikacji: 13.06.2016

Źródło finansowania: Praca nie jest finansowana z żadnego źródła. Konflikt interesów: Autorzy deklarują brak konfliktu interesów.

\author{
Adres do korespondencji: \\ Michał Ławiński \\ ul. Żwirki i Wigury 61 \\ 02-091 Warszawa \\ tel. kom.: 501702899 \\ e-mail: michal-lawinski@wp.pl \\ Katedra i Klinika Chirurgii Ogólnej, Gastroenterologicznej \\ i Onkologicznej \\ Warszawski Uniwersytet Medyczny
}

